\title{
Implementation of IDA* Algorithm to Translate Words From Indonesian Language Into Sundanese
}

\author{
Aninda Muliani, M.Kom. \\ Universitas Prima Indonesia \\ Medan, Indonesia \\ anindamh@gmail.com \\ Ray Cefri \\ Universitas Prima Indonesia \\ Medan, Indonesia \\ ray.cefri@gmail.com
}

\author{
David Arnold Sibuea \\ Universitas Prima Indonesia \\ Medan, Indonesia \\ davidarnold886@gmail.com \\ Rut Stepane
Universitas Prima Indonesia
Medan, Indonesia
princesr279@gmail.com
}

\begin{abstract}
Sundanese are tribes from West Java and Banten that use their own local language known as Sundanese. The large number of local residents who still use Sundanese in communicating daily is an obstacle in increasing tourist visits to the area. Then a translator is needed which can be used as a liaison between tourists and local residents so that there is no miscommunication between the two. But the increasing number of tourists, there is a lack of the number of translators needed, so it needs to be made a translator application by utilizing the development of computer technology. The application developed is an Indonesian-Sundanese translator in the form of words using the IDA* algorithm. This algorithm is an A* algorithm whose depth is limited to each search iteration. Although the time complexity is higher than that of the $\mathrm{A}^{*}$ algorithm, the IDA* algorithm does not require as much memory as needed by the A* algorithm. There are one thousand single words can be translated in this application. It indicates that the IDA* algorithm can be implemented to convert translate words in Indonesian and Sundanese based on the estimation value of the smallest total cost of each word stored in the database, where the word that has the smallest total cost estimationcan be selected as a result of the translation.
\end{abstract}

Keywords-Translation, Indonesian-Sundanese Language, IDA* Algorithm

\section{INTRODUCTION}

Sundanese are tribes from West Java and Banten that use their own local language known as Sundanese. There are still many local residents who still use Sundanese in communicating everyday as an obstacle in increasing tourist visits to the area. Then a translator is needed which can be used as a liaison between tourists and local residents so that there is no miscommunication between the two. But the increasing number of tourists, there is a lack of the number of translators needed, so it needs to be made a translator application by utilizing the development of computer technology.

Inaccordance with the results of Hidayatullah's research, Romdhini and Irwansyah showed that the use of the Iterative Deepening A* algorithm (IDA*) can be used to find the best solution for Otello games, so that the best strategies and tactics can be obtained in completing the game. Whereas in this study, the IDA* algorithm is used for searching the same word in a dictionary so that the application can show the translation of the word if it is already stored in the database

The application developed is an IndonesianSundanese translator in the form of words using the IDA* algorithm. This algorithm is an $A^{*}$ algorithm whose depth is limited to each search iteration. Even though the time complexity is higher than that of the $\mathrm{A}^{*}$ algorithm, the IDA* algorithm does not require as much memory as needed by the A* algorithm. Then the IDA* algorithm is used in this study.

\section{Case Study of Problems}

The problems to be examined in this study can be formulated as follows: "How does the IDA algorithm work to convert as translators of Indonesian words intoSundanese".

\section{Scope of Problems}

The problem limits in this study are as follows:

a. The algorithm used is IDA*.

b. Translation is done in the form of words. 
c. The programming language used is the Microsoft Visual Basic 2010 programming language.

d. Bahasa pemrograman yang digunakan adalah bahasa pemrograman Microsoft Visual Basic 2010.

e. Database objects using SQL Server 2008.

Objectives and Benefits of Research

The purpose of this study is to find out how the IDA* algorithm works for translators of Indonesian words into Sundanese.

The benefits of this research are as follows::

a. Increasethe insight and knowledge of researchers in developing dynamic programs for translators of Sundanese-Indonesian words using the IDA* algorithm.

b. Helping users in translating words from Indonesian into Sundanese and vice versa so that they can communicate well with local residents who still use Sundanese in daily communication.

c. Become a reference material for other researchers who will develop dynamic programs in the future, especially those that use the IDA algorithm.

\section{METHOD}

The stages of research can be seen in Figure 1.

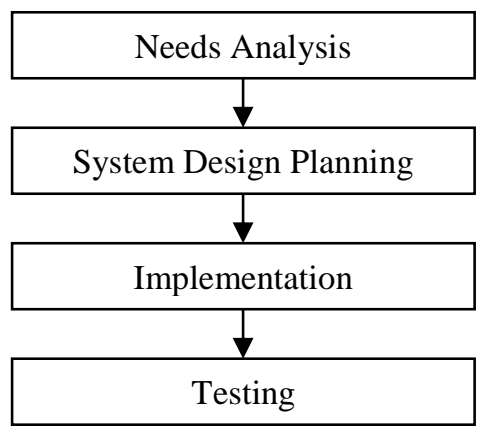

Figure 1. Research Method

Theresearch method in making word translation applications as in Figure 1 consists of 4 stages, namely needs analysis, design, implementation and testing. In the needs analysis phase, research and observations are carried out about the problems and needs in the translation of the Indonesian-Sundanese word. From these problems and needs, we can conclude the solution to the problem and make a general description of the application that will be made.

The design stage is the development of a general description of the system. In the design phase, it is explained in more detail about the contents of the application that is made, namely by creating a Unified Modeling Language (UML) diagram that includes use case and activity diagrams and making input and output designs. After the design stage is complete, the implementation phase is carried out, namely translating the design into Visual Studio 2010language source code.

Translation of words from Indonesian to Sundanese and vice versa uses the Iterative Deepening A* (IDA*) algorithm. Iterative Deepening A* algorithm is a combination of IDS and $\mathrm{A}^{*}$ algorithms. Iterative Deepening Search algorithm is a technique that combines search advantages using the Breadth First Search (BFS) technique in terms of complete and optimal and the advantages of the search technique for Depth First Search (DFS) in terms of Space Complexity. While Algorithm A* (A Star) is a graph / tree search algorithm that looks for paths from one starting point to a predetermined end point. The advantages of the $\mathrm{A}^{*}$ algorithm are costs calculated from actual costs plus estimated costs. While the advantages of the IDS algorithm combine the advantages of Breadth First Search (complete and optimal) and the advantages of Depth First Search (requires a little memory). IDS is a Blind Search algorithm that does an iterative search using the Depth Limited Search (DLS) search starting with a limit of 0 .

The IDA* search algorithm method uses the same evaluation function as the $\mathrm{A}^{*}$ method, as follows :

$f(n)=g(n)+h(n)$

Where:

$\mathrm{f}(\mathrm{n})=$ estimated total cost of a path from the initial node to the destination node through node $n$

$\mathrm{g}(\mathrm{n})=$ the cost of a path to reach node $\mathrm{n}$ from the initial node

$h(n)=$ cost estimate for a path

The way IDA works * is as follows :

a. The threshold value is determined;

b. $\quad f(n)=g(n)+h(n)$ is calculated in each iteration;

c. If $f(n)$ threshold, the node is prune;

d. If the goal node is reached with a smaller price, the threshold value is returned;

e. If the entire iteration has ended without reaching the goal node then another iteration starts with a larger threshold value;

f. The new threshold value is the minimum value of the node prune in the previous iteration;

g. The threshold value for the first iteration is set to the value in the initial state.

\section{RESULT AND DISCUSSION}

System Analysis

The application of the translation of words from Indonesian to Sundanese is done by searching for the same word in the Indonesian-Sundanese dictionary so that the word translation can be obtained by the IDA method *. Before doing a word translation, a case folding is done first for the word to be translated 
because in this study only used for translation in the basic words.

\section{Kata \\ Ditemukan}

The schematic translation of words in Sundanese Indonesian can be seen in Figure 2.

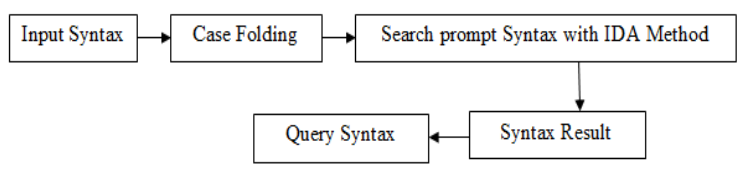

Figure 2. Word Translation Scheme

\section{System Planning}

System design aims to explain and explain the software that will be built as a whole. Software modeling provides an overview for users or users of new applications in explaining the processes that occur in an application so as to provide convenience for the user. Modeling software used in building word translation applications is as follows:

a. Use Case Diagram

The use case diagram in the word translation application can be seen in Figure .

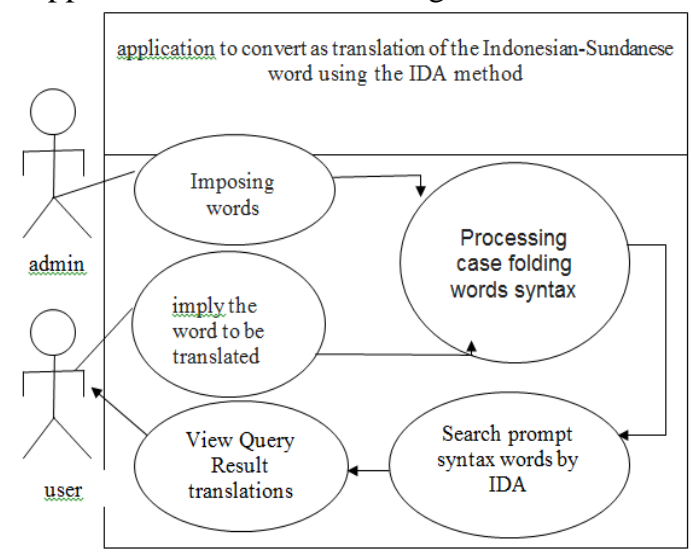

Figure 3. Use Case Diagram

In Figure 3 above, the use case diagram of the word translation application has five main processes, namely inputting the words done by the admin and storing them into the database, inputting words that will be translated by the user, folding case process, doing word search with IDA* algorithm and display the translation results.

Furthermore, the definition of person is an explanation of what is done by the persons involved in the software built. The description of the persons involved in this application can be seen in Table 1 .

Table 1. Definition of Persons

\begin{tabular}{|l|l|l|}
\hline No. & Person & \multicolumn{1}{|c|}{ Description } \\
\hline 1. & Admin & $\begin{array}{l}\text { To do login and processing } \\
\text { manipulation (add, change, } \\
\text { delete) al contents on } \\
\text { application convert syntax } \\
\text { translation words indonesia } \\
\text { into Sundanese }\end{array}$ \\
\hline 2. & User & $\begin{array}{l}\text { Query Searching results } \\
\text { translation with input syntax } \\
\text { words Indonesia into } \\
\text { sundanese. }\end{array}$ \\
\hline
\end{tabular}

b. Activity Diagram

Activity diagramin word translation applications can be seen in Figure 4.

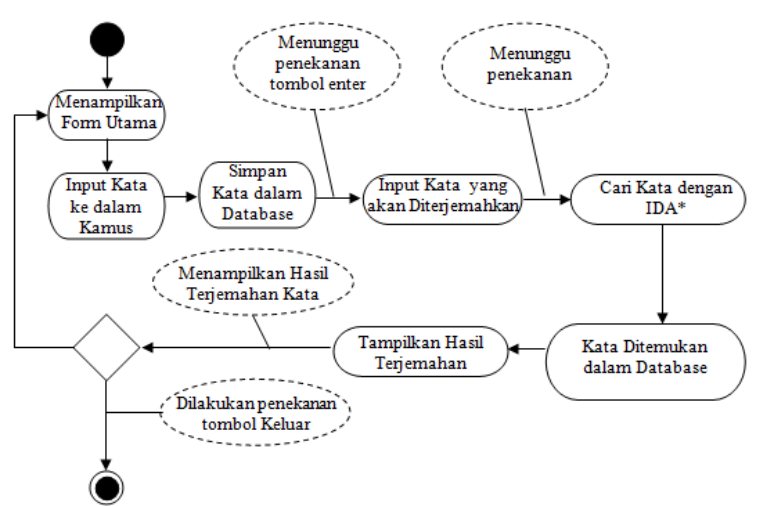

Figure 4. Activity Diagram

Based on Figure 4 above, it can be seen that when the application is run it will display the main form, the admin will input the words in Indonesian and Sundanese into the application, then the word is stored in the database, then the user inputs words either in Indonesian or Sundanese so that the word search process can be carried out in the database so that the translation can be determined, the translation results will be displayed using the IDA* algorithm.

\section{c. Database Design}

Databaseis a data storage area. Database is used for data processing operations attention to speed of data processing, minimum time used in data tracking, data storage capabilities, and ease in updating data. In this case the database editor used is Microsoft SQL Server.

Thestructure of database tables designed are Word Tables. Word tables are tables designed to store wordIndonesian Sundanese data inputted by the admin. The structure of Word tables as follows:

Table 2. Words 


\begin{tabular}{|l|c|c|c|l|}
\hline Nama Field & Tipe & Nilai & Kata Kunci & Keterangan \\
\hline KdKata & Varchar & 6 & Primary Key & Kode Kata \\
\hline BInd & Varchar & 100 & & Kata dalam Bahasa Indonesia \\
\hline BSunda & Varchar & 100 & & Kata dalam Bahasa Sunda \\
\hline
\end{tabular}

System Implementations

Stepsfor system implementation are as follows :

a. Device Required

Indonesian Sundanese translator application that has been designed for desktop-based application. This Indonesian and Sundanese translation application can be implemented by requiring software and hardware:

1) Hardware

a) Notebook Intel Core i3 above;

b) Storage 500 Giga Byte;

c) Minimum RAM 1 Giga Byte;

d) Monitor Desktop;

e) Mouse and Keyboard;

f) Print Device.

2) Software

a) Microsoft Visual Studio 2010

b) SQL Server 2008

c) Operating System minimum Requirements Microsoft Windows Seven ( 32 bit) or Microsoft Windows 8 (64 bit);

d) Microsoft DotNet Framewrok 4.0

b. User Interface

User Interface of the translation of Indonesian and Sundanese words using the IDA* algorithm is as follows:

1) Login Form Interface

The Login Form is used to get access rights to use this translator application so that users can be distinguished as admin or user only. If logging in as an admin, it can change the contents of the dictionary and do word translations, while login users can only do translations. Login as admin must input admin username and password field. The display of the login form can be seen in Figure 5.

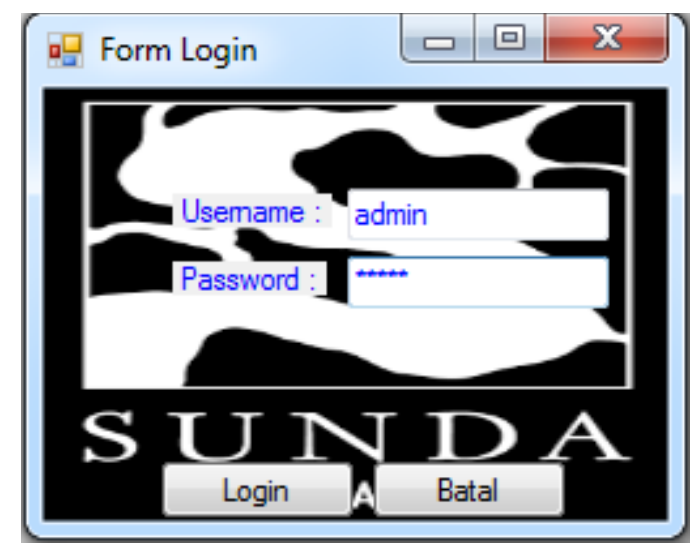

Figure 5. Login Form Interface

2) Menu Form Interface

Form Menu is a form Menu to display selected menus in the Indonesian-Padang Language Translation Application that can be selected by the user. This form contains a File Menu which consists of two sub menus, that is the Dictionary used to input words in the Indonesian and Sundanese discussion, as well as the Log Out sub menu used to logout from the application. Translation is used to process translations per word and per sentence in Indonesian and Sundanese and vice versa using the IDA* algorithm while the Exit menu is used to exit the system.

While the appearance of the Form Menu display is as follows:

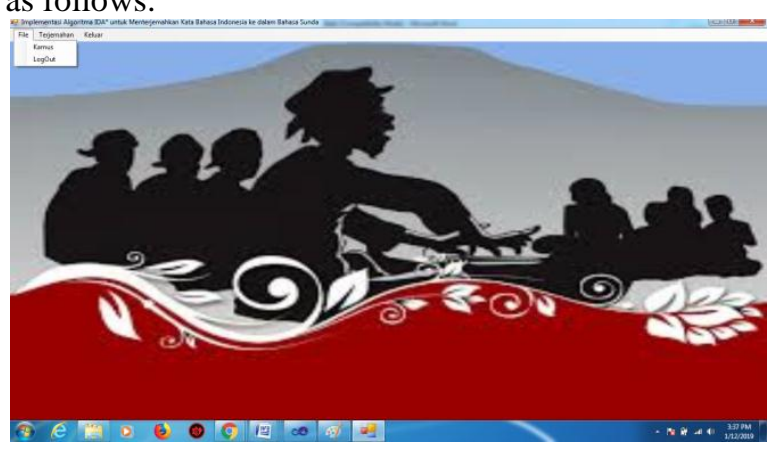

Figure 6. Menu Form Interface

\section{3) Dictionary Form Interface}

Dictionary Input Form is a form that is used to input words in Indonesian and Sundanese. This form displays dictionary data, as Add, Change, and Delete words. The display of the Dictionary Input Form display is as follows: 


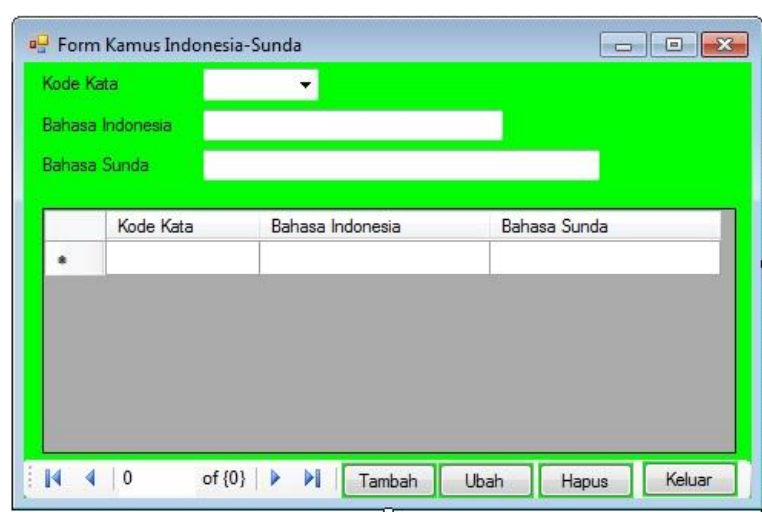

Figure 7. Dictionary Form interface

4) Translation Form Interface

This form is a form that is used to carry out the translation process per word in Indonesian and Sundanese so that the translation can be known using the ID* algorithm. The display of the Display Word Translation Form is as follows:

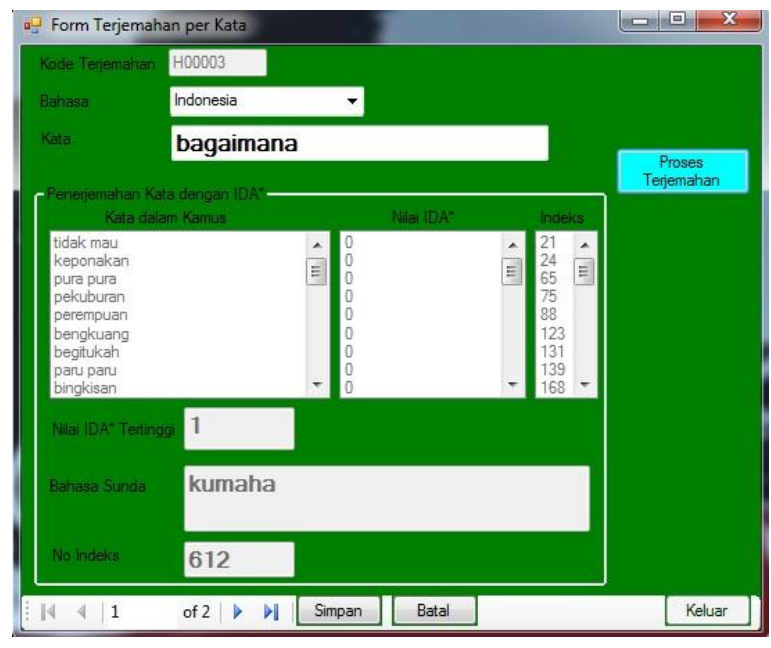

Figure 8. Translation Form Interface From Indonesian Language to Sundanese Language

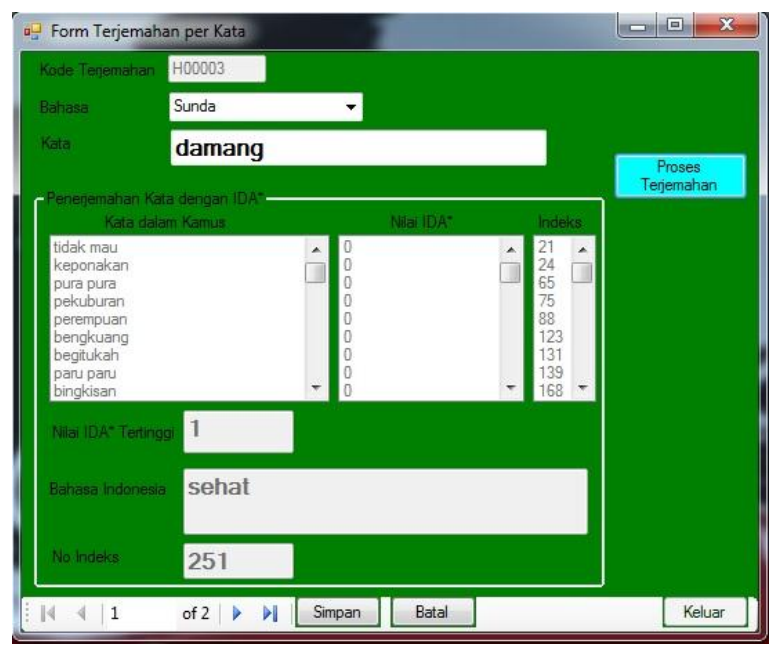

Figure 9. Translation Form Interfacefrom Sundanese Languageto Indonesian Language

\section{c. Discussion}

Based on the results of the application's implementation of the translation of the words in Indonesian and Sundanese using the IDA* algorithm, we can know the strength and weakness of the application.

1) Advantages of Application

Advantages of this translator application are as follows:

a) $98 \%$ of one thousand single words is succeed to be translated from Indonesian into Sundanese and vice versa as long as the words have been saved in the database.

b) The existence of the database is for storing data so the translation results can be accessed again whenever needed by the user.

2) Disadvantages of Application

Disadvantages that the writer found from the Indonesian-Sundanese translator application using the IDA algorithm are as follows :

a) This application cannot be used to translate words that contain affixes, suffixes and prefixes so that the translation results for sentences are not perfect enough.

b) This application cannot be run on any network because it still uses a single user system.

\section{CONCLUSION}

Based on the observation of the research conducted, it can be concluded that the implementation of the algorithm IDA* for Indonesian and Sundanese translator applications is carried out based on the exact number of letters that will be translated with the words stored in the dictionary, then calculated the estimated total cost per word and the translation word is a word that has the smallest total cost estimation value and the algorithm IDA* can be implemented to do translation of Indonesian and Sundanese based on the estimated smallest total cost of each word stored in the database, which is the word has a total estimated value the smallest cost can be chosen as a result of the translation.

\section{REFERENCES}

[1] Halilintar Nur Hidayatullah A, *. Mamika Ujianita Rhomdinib . Irwansyah, Implementasi Algoritma Ida* (Iterative Deepening A*) Dalam Menentukan Solusi Terbaik Pada Permainan Othello Dengan Simulasi Matlab, Eigen Mathematics Journal 
Volume 1 No 1 Juni 2018 E- Issn: 2615-3270 PIssn: 2615-3599.

[2] Fahrurrozi, Implementasi Algoritma Iterative Deepening A* Dan Metode Pruning Pada Solusi Permainan Puzzle Flow Free Color, Jurnal Ilmiah Komputer Dan Informatika (Komputa) 45 Edisi. .. Volume. .., Bulan 20.. Issn : 2089-9033.

[3] Jackri Hendrik, Penerapan Algoritma InterativeDeepening Search (Ids) Dalam Penyelesaian Permainan Teka-Teki Kakuro, Penerapan Algoritma Interative-Deepening Search (Ids) Dalam Penyelesaian Permainan Teka-Teki Kakuro, Majalah Ilmiah INTI, Volume 12, Nomor 3, September 2017 ISSN 2339-210X.

[4] Christian Yulius Setiawan ${ }^{1}$, Andrian Rakhmatsyah², Rimba Widhiana Ciptasari³ ${ }^{3}$, Studi Dan Implementasi Metode Algoritma Ida* Untuk Pencarian Jalur Terpendek Dengan Studi Kasus Yellow Pages Kota Bandung Menggunakan Teknologi Wap, Teknik Informatika, Fakultas Teknik Informatika, Universitas Telkom.

[5] Adelia dan Setiawan, Implementasi Customer Relation Management (CRM) pada Sistem Reservasi Hotel berbasisi Website dan Desktop, Universitas Kristen Maranatha, Bandung, Vol. 6, No. 2:113-126. Enterprise, Jubilee. 2010.

[6] Ladjamuddin, 2013, Reakayasa Perangkat Lunak, Penerbit Andi, Yogyakarta.

[7] Rochmawati dan Kusumaningrum, 2016, Studi Perbandingan Algoritma Pencarian String dalam Metode Approximate String Matching untuk Identifikasi Kesalahan Pengetikan Teks, Jurusan Ilmu Komputer/Informatika, Fakultas Sains dan Matematika, Universitas Diponegoro, Semarang. 